\title{
Biological Control of Tick Populations: Review and Reflections
}

\section{Controle Biológico da População de Carrapatos: Revisão e Reflexões}

\author{
Norma V. Labarthe
}

\begin{abstract}
LABARTHE, N.V. Biological Controle of Tick Populations: Review and Reflections. Cad. Saúde Públ., Rio de Janeiro, 10(1): 47-52, Jan/Mar, 1994.

This study is concerned with aspects of the relationship between ticks and their hosts that have a bearing on biological control of tick populations. It proposes control methods based on a program that would combine development of an effective vaccine with genetic selection of hosts.
\end{abstract}

Key words: Resistance to Ticks; Boophilus microplus; Dermacentor andersoni; Rhipicephalus sanguineus

Ticks constitute one of the most important groups of arthropods in terms of effects on animal health. They debilitate the host by feeding on it (Kaufman \& Philips, 1973); they can cause paralysis (Murnaghan \& O'Rourke, 1978) and immunological disturbances (Rossi, 1990) through direct effects resulting from inoculation of their saliva; and they can also transmit high-morbidity pathogenic agents (Hoogstraal, 1985). In addition, they can act as vectors between domestic animals, sylvatic animals, and humans (Hoogstraal, 1991).

Given the scale of the harmful effects of ticks, it is essential that their population be controlled. Present control methods involve the undesirable expedient of indiscriminate application of acaricides. To reduce our reliance on these chemical products, it is necessary to embark on programs that include habitat management, genetic selection of hosts, and development of a vaccine capable of inducing host resistance to ticks.

\section{LITERATURE REVIEW}

The first account of host immunity to ticks appears to be one written by Nuttal (1911), which refers to the phenomenon of natural immunity in humans. From the 1930's

\footnotetext{
${ }^{1}$ Departamento de Patologia e Clínica Veterinária Faculdade de Veterinária. Rua Vital Brazil Filho, 64. Niterói, RJ, 24230-340, Brasil.
}

onwards, the first investigations into host resistance to ticks began to appear, and since them innumerable studies on the immunological aspects of the host-tick relationship have been carried out.

Trager (1939a) carried out pioneering studies that gave evidence of acquired immunity to ticks. Later, Feldman-Muhsam (1964) observed that rats, after successive infestations with Rhipicephalus sanguineus, became immune to ticks, a process that was considered to constitute immunization of the host.

Wikel \& Allen (1976) transferred resistance against Dermacentor andersoni by passing lymph node cells from resistant guinea-pigs to susceptible guinea-pigs. Later, Wikel \& Allen (1977) also observed that complement depletion did not affect acquisition of resistance to $D$. andersoni, but that it did block that expression of already acquired resistance.

Allen et al. (1977) demonstrated that salivary gland antigens of $D$. andersoni were present in the skin of infested guinea pigs. Allen et al. (1979) also noted that these salivary gland antigens were associated with dendritic cells in the epidermis, and suggested that the latter were Langerhans' cells.

Nithiuthai \& Allen (1984a) observed that the number of Langerhans' cells decreased in areas where ticks were attached to susceptible guinea pigs, while in resistant animals the number of Langerhans' cells in the epidermis increased. Later, Nithiuthai \& Allen (1984b) 
showed that depletion of Langerhans' cells made it impossible for animals to acquired or express resistance to ticks. Nithiuthai \& Allen (1985) also suggested that Langerhans' cells, like Ia positive macrophages, could act as presenting cells for salivary antigens, assisting in the development of an immune response to ticks.

Whellen (1986) observed that levels of resistance to ixodid ticks were not necessarily directly correlated to serum immunoglobulin titres, suggesting the possible presence of other mechanisms that might be important in the immune response.

Worms et al. (1988) transferred different fractions of serum from resistant guinea pigs to susceptible guinea pigs, and observed that purifed $I_{g G}$ or purified $\operatorname{IgG}_{2}$ did not, on their own, confer resistance, whereas whole serum did. Worms therefore suggested that both subclasses of IgG were necessary for the expression of resistance, or that $I_{g G_{1}}$ required $\mathrm{IgE}$ in order to induce resistance.

Studies on the heritability of resistance to ticks showed that individual potential for resistance is partly determined by a genetic component.

Villares (1941) observed that the degree of acquired immunity to ticks is an individual characteristic, that it is linked to breed, and that, in the case of cattle, breeds of European origin are more susceptible to ticks than those of Indian origin (Brahma cattle). Roberts (1968) demonstrated that different breeds of cattle are equally susceptible to initial infestation with Boophilus microplus.

However, over time, resistance is expressed in different ways, as parasitization proceeds.

Roberts therefore concluded that individual potential for resistance is innate, and that tick infestation is the necessary stimulus that leads to the acquisition of resistance.

Wharton et al. (1970) studied the heritability of the $B$. microplus resistance factor in cattle, and concluded that heretability is sufficiently high to promote rapid progress towards resistance in a herd.

Stear et al. (1982) went further in their research into genetic host resistance to ticks, with a study of the Major Histocompatibility
System (MHs). They studied 199 cattle and concluded that at least two antigens are linked to bovine resistance to $B$. microplus, and one to susceptibility. Soon after, Newman \& Antczak (1983) considered it surprising that resistance to an ectoparasite should be so strongly associated with MHs, given that previous studies on other associations had failed to yield any significant results. Despite this, they considered that the association might be important, given that it is known that bovine resistance to ticks involves important genetic and immunological factors.

At the same time as it was being concluded that natural host resistance to ticks involves the expression of a genetically orientated immune response, researchers began to look for antigens that might induce artificial resistance in hosts.

Trager (1939b) innoculated guinea pigs with various extracts of tissue from $D$. variabilis, and concluded that an antigenic substance was present in the digestive tract and cephalic glands of partially engorged females, in the salivary glands of fed and unfed ticks, and in total larvae extracts. Since then, various studies have been carried out using different hosts, ticks, and tissues as antigenic sources. Researchers have used extracts of eggs, of larvae, of nymphs, of partially engorged females of adult ticks, of salivary glands, of saliva and the cement as antigenic sources. These antigens produced an immune response, but a challenge with a homologous tick rarely showed a positive correlation with the response obtained (Gregson, 1941, 1970; Riek, 1958; 1959; Tornado \& Gutierrez, 1967; McGowan et al., 1980; Labarthe, 1981; Berne, 1982, Wilkinson \& Allen, 1983; Brown et al., 1984; Johnston et al., 1986; Gordon \& Allen, 1987).

From 1981, assays were developed adding adjuvants to these different antigens.

Researchers used Freund's complete adjuvant (FCA), Freund's incomplete adjuvant (FIA), and aluminium hydroxide. All the adjuvants were effective in modulating the immune response to the antigens, but were ineffective in terms of inducing resistance to ticks (McGowan et al., 1981; Labarthe, 1981; 
Berne, 1982; Wilkinson \& Allen, 1983; Willadsen et al., 1988). Only Brown et al. (1984) described the induction of a satisfactory response in the host, with FIA emulsion and salivary antigens; this approach conferred a similar level of resistance to that obtained through active sensitization with ticks.

In parallel, various studies were carried out in an attempt to purify and identify the antigen fractions that were most effective in inducing resistance (Tatchell \& Binnington, 1971; Geczy et aal., 1971; O'Hagan et al., 1973; Dickinson et al., 1976; Scheleger \& Lincoln, 1976; Higgs et al., 1976; Willadsen, 1976; Willadsen \& Riding, 1979; Kemp et al., 1983; Willadsen \& McKenna, 1983; Brown et al., 1984; Johnston et al., 1986), but no progress was reported in terms of obtaining an effective vaccine.

aAgbede \& Kemp (1986) observed that ticks fed on cattle immunized with fractions of an extract derived from adult female $B$. microplus had more leucocytes in their intestine than ticks fed on susceptible cattle. They detected granulocytes associated with lesions in the tick intestine, suggesting that this reaction had played a part in the success of the vaccination. They proposed that the primary intestinal lesion could lead to possibly significant reactions against other tissues in the tick.

Opedebeek et al. (1988) immunized cattle with FIA emulsion and intestinal extract from partialy engorged female $B$. microplus. They observed a protection rate of $87 \%$, demonstrated significant levels of antibodies in the serum of immunized animals, and showed that there was a positive correlation between protection levels and antibody levels.

\section{DISCUSSION}

Ticks are ectoparasites that act as vectors for various disease agents that attack different hosts. These agents often cause high morbidity and mortality, which together with the damage inflicted by the tick itself lead to significant losses. In spite of the growing importance of ticks, and in spite of the large numbers of studies and wide variety of information on the subject, none of the relevant host-parasite systems is as yet fully understood. However, it seems clear that the achievement of biological control will largely depend on efforts to bring about genetic improvements, and on the development of an affective vaccine.

Programs aimed at genetic improvement should make use of animals that can transmit resistance to their offspring, thus reducing the susceptibility of a population in a given enzootic area. This would bring about a decline in the region's parasite load, which would in turn contribute to reducing the need for chemical control methods. To carry out the genetic program, it would be necessary to have greater knowledge of genetic indicators implicated in resistance, such as the Major Histocompatibility Antigens (MHs). This would make it possible to identify reproductive animals with high innate resistance at an early age, and these animals could then be recommended for genetic dissemination of resistance in enzootic areas.

Development of a vaccine would aid in the control of ticks, conferring resistance on hosts with no previous contact with the parasite, and also maintaining resistance in hosts that had spent long periods of time away from ticks. Developing such a vaccine would depend on producing both an antigen capable of stimulating a satisfactory immune response and an adjuvant to guarantee the intensity and duration of the immune response obtained. However, since the vaccine would have to be produced in large quantities, it would not be feasible to obtain the antigen from a process that used ticks themselves as a source. Thus, as well as identifying an effective antigen, it would be necessary to develop technology capable of synthecsizing it in large quantities.

Biological control of ticks, carried out through a coordinated program using a variety of methods, would lead to a decline in the use of chemical control techniques. The latter, when used improperly, not only cause certain strains of ticks to develop drug resistance, but are also responsible for environmental 
pollution. With regard to immunity, it is essential that the development of a vaccine be linked to a program of genetic selection designed to improve host resistance to ticks.

\section{ACKNOWLEDGEMENTS}

To Prof ${ }^{a}$ Maria Isabel Doria Rossi.

\section{RESUMO}

LABARTHE, N. V. Controle Biológico da População de Carrapatos: Revisão e Reflexões. Cad. Saúde Públ., Rio de Janeiro, 10 (1): 47-52, jan/mar, 1994.

Este artigo estuda os aspectos da relação hospedeiro-parasita que têm significado no controle da população de carrapato. São propostos métodos de controle baseados em um programa que combinaria o desenvolvimento de uma vacina efetiva com a seleção genética dos hospedeiros.

Palavras-Chave: Resistência aos Carrapatos; Boophilus microplus; Dermacentor andersoni;

Rhipicephalus sanguineus

\section{REFERENCES}

ALLEN, J. R.; DOUBE, B. M. \& KEMP, D. H.; 1977. Histology of bovine skin reactions to Ixodes holocyclus Neumann. Canadian Fournal of Comparative Medicine, 41: 26-35.

ALLEN, J. R.; KHALIL, H. M. \& WIKEL, S. K., 1979. Langerhans cells trap tick salivary gland antigens in tick-resistant guinea pigs. The fournal of Immunology, 122: 563-565.

BERNE, M. E. A., 1982. Resposta Imunológica Humoral de Bovinos ao Extrato de lavras de Boophilus microplus (Canestrini, 1887). Tese de Mestrado, Porto Alegre: Faculdade de Veterinária, Universidade Federal do Rio Grande do Sul.

BROWN, S. J.; SHAPIRO, S. Z. \& ASKENASE, P. W., 1984. Characterization of tick antigens inducing host imune resistance. I. Immunization of guinea pigs with Amblyomma americanum - derived salivary gland extracts and identification of an important salivary gland protein with guinea pig anti-tick antibodies. The fournal of Immunol-ogy, 133: 3319-3325.
DICKINSON, R. G.; O'HAGAN, J. E.; SCHOTZ, M.; BINNINGTON, K. C. \& HEGARTY, M. P., 1976. Prostaglandin in the saliva of the cattle tick Boophilis microplus. Australian Fournal of Experimental Biology and Medical Sciences, 54: 475-486.

FELDMAN-MUHSAM, B., 1964. Laboratory colonies of Rhipicephalus. Bulletin of the World Health Organization, 31: 587-589.

GECZY, A. F.; NAUGTON, M. A.; CLEGG, J. B. \& HEWETSON, R. W., 1971. Esterases and a carbohydrate-splitting enzyme in the saliva of the cattle tick, Boophilus microplus. The fournal of Parasitology, 57: 437-438.

GORDON, J. R. \& ALLEN, J. R., 1987. Isolation and characterization of salivary antigens from the female tick, Dermacentor andersoni. Parasite Immunology, 9: 337-352.

GREGSON, J. D., 1941. Host immunity to ticks. Proceedings of the Entomological Society of British Columbia, 38: 12-13. , 1970. Antigenic properties of tick secretions. The Fournal of Parasitology, 56: 1038-1039.

HIGGS, G. A.; VANE, J. R.; HART, R. J.; POTTER, C. \& WILSON, R. G., 1976. Prostaglandins in the saliva of the cattle tick, Boophilus microplus. Bulletin of Entomological Research, 66: 665-670.

HOOGSTRAAL, H., 1991. Tickborne diseases of humans. A history of environment and epidemiological changes. In: Tick-transmitted Diseases (J. D. Hoskins, ed.), The Veterinary Clinics of North America, 21: 1-260. , 1985. Argasid and nuttaliellid ticks as parasites and vectors. Advances in Parasitology, 24: 135-140.

JOHNSTON, L. A. Y.; KEMP, D. D. \& PEARSON, R. D., 1986. Immunization of cattle against Boophilus microplus using derived from adult female ticks: Effects of induced immunity on tick population. International fournal of Parasitology, 16: 27-34.

KAUFMAN, W. R. \& PHILIPS, J. E., 1973. Ion and water balance in the ixodid tick Dermacentor andersone: I Routes of ion and water excretion. Fournal of Experimental Biology, 58: 528.

KEMP, D. H.; HALES, J. R.S.; SCHELEGER, A. V. \& FAWCETT, A. A., 1983. Comparison of cutaneous hyperemia in cattle elicited by larval of Boophilus microplus and by prostaglandins and other mediators. Experientia, 39: 725-727.

LABARTHE, N. V., 1981. A Resposta Imunológica de Bovinos Contra a Saliva de Boophilus microplus (Canestrini, 1887). Tese de Mestrado, Porto 
Alegre: Faculdade de Veterinária, Universidade Federal do Rio Grande do Sul.

McGOWAN, M. J.; BAKER, R. W.; HOMER, J. T.; McNEW, R. W. \& HOLSCHER, K. H., 1981. Success of tick feeding on calves immunized Amblyomma americanum (Acari: Ixodidae) extract. Fournal of Medical Entomology, 18: 328332.

McGOWAN, M. J.; HOMER, J. T.; O’DELL, G. V.; McNEW, R.W. \& BARKER, R.W., 1980. Performance of ticks fed on rabbits inoculated with extracts derived from homogenized ticks Amblyomma maculatum Kock. The Fournal of Parasitology, 66: 42-48.

MURNAGHAN, M. F. \& O'ROURKE, F. J., 1978. Tick paralysis. In: Arthropod Venoms (S. Bettini, ed.), p. 419, New York-Springer: Verlag.

NEWMAN, M. J. \& ANTCZAK, D. F., 1983, Histocompatility polymorphims of domestic animals. Advances in Veterinary Science and Comparative Medicine, 27: 1-76.

NITHIUTHAI, S. \& ALLEN, J. R., 1984a. Significant changes in epidermal Langerhaans cells of guinea pigs infested with ticks (Dermacentor andersoni). Immunology, 51: 133-141.

, 1984b. Effects of ultraviolet irradiation

on the acquisition and expression of tick resistance in guinea pigs. Immunology, 51: 153-159.

, 1985. Langerhans cells present tick antigens to lymph node cells from tick-sensitized guinea pigs. Immunology, 55: 157-163.

NUTTAL, G. H. F., 1991. Symptoms following tick-bites in man. Parasitology, 4: 89-93.

O'HAGAN, J. E.; SCHOTZ, M.;BINNINGTON, K. C. \& HEGARTY, M. P., 1973. A slow reacting substance in the saliva of the cattle tick Boophilus microplus. Proceedings of the Australian Biochemistry Society, 6: 75.

OPEDEBEEK, J. P.; WONG, J. Y. M.; JACKSON, L. A. \& DOBSON, C., 1988. Vaccines to protect Hereford cattle against the cattle tick, Boophilus microplus. Immunology, 63: 363-367.

RIEK, R. F., 1958. Studies on the reaction of animals to infestation with tocks. III. The reactions of laboratory animals to reprated subletal doses of egg extracts of Haemophylasis bispinosa Neumann. Australian Fournal of Agricultural Research, 9: 830-841.

, 1959. Studies on the reaction of animals to infestation ticks. IV. The protein components of tick extracts. Australian fournal of Agricultural Research, 10: 604-613.

ROBERTS, J. A., 1968. Acquisition by the host of resistance to the cattle tick, Boophilus microplus. The Fournal of Parasitology, 54: 657-662.
ROSSI, M. I. D., 1990. Efeitos biológicos da saliva de Boophilus microplus (Canestrini, 1887) sobre o sistema imuno de Mus musculus $L$. Tese de Mestrado, Seropédica: Ciências em Patologia Veterinária, Universidade Federal Rural do Rio de Janeiro.

SCHELEGER, A. V. \& LINCOLN, D. T., 1976. Boophilus microplus: Characterization of enzimes introduced into he host. Australian fournal of Biological Sciences, 29: 487-497.

STEAR, M. J.; NEWMAN, M. J.; NICHOLAS, F. W.; BROWN, S. C. \& HALROYD, R. G., 1982. Tick resistance and the major histocompatibility system. New South Wales Veterinary Proceedings, 18: 36-38.

TATCHELL, R. J. \& BINNINGTON, K. C., 1971. Active constituent of the saliva of the cattle tick B. microplus. Proceedings of the 3rd International Congress of Acarology, pp. 745-748.

TORRADO, J. M. G \& GUTIERREZ, R. O., 1967. Repuesta sorológica del bovino inoculado com algunas formas evolutivas de la "garrapata común del ganado" y su interpretación imunológica. Revista de Investigaciones Agropecuarias, INTA IV: 45-64.

TRAGER, W., 1939a. Acquired immunity to ticks. The fournal of Parasitology, 25: 57-81. , 1939b. Further observation on acquired immununity to the tick Dermacentor variabilis Say. The Fournal of Parasitology, 25: 137139.

VILLARES, J. B., 1941. Contribuição ao estudo da resistência e suscepitibilidade genética dos bovinos ao Boophilus microplus. Boletim de Indústria Animal, 4: 60-80.

WHARTON, R. H.; UTECH, K. B. \& TURNER, H. G., 1970. Resistance to the cattle tick, Boophilus microplus in a herd of Australian Illawara Shorthorn cattle: Its assessment and heritability. Australian Fournal of Agricultural Research, 21: 163-168.

WHELLEN, A. C., 1986. Characterization of humoral responseviness of cattle and guinea pigs to infestations with ixodid ticks. Dissertation $A b$ stracts International, 47: 1481-1482.

WIKEL, S. K. \& ALLEN, J. R., 1976. Acquired resistance to ticks. I. Passive transfer resistance. Immunology, 30: 311-316. , 1977. Acquired resistance to ticks. III. Cobra venom factor and the resistance response. Immunology, 32: 457-465.

WILKINSON, P. R. \& ALLEN, J. R., 1983. A test of the efficacy of immunizing cattle against rock moutains wood ticks. Fournal of the Entomological Society of British Columbia, 80: 37-41. 
WILLADSEN, P., 1976. Allergenic activity of an esterase from Boophilus microplus. FEBS Letters, 72: 346-348.

WILLADSEN, P. \& McKENNA, R.V., 1983. Binding of antigens to tissues: The example of Boophilus microplus and bovine skin. International Fournal for Parasitology, 13: 593-598.

WILLADSEN, P.; McKENNA, R.V. \& RIDING, G. A., 1988. Isolation from the cattle tick, Boophilus microplus, of antigenic material capable of eliciting a protective immunological response in the bovine host. International Fournal for Parasitology, 18: 183-189.
WILLADSEN, P. \& RIDING, G. A., 1979. A characterization of a proteolitic-enzyme inhibition with allergenic activity. Biochemistry fournal, 177: 41-47.

WORMS, M. J.; ASKENASE, P. W. \& BROWN, S. J.; 1988. Requirement for host Fc receptors and IgG antibodies in host immune responses against Rhipicephalus appendiculatus. Veterinary Parasitology, 28: 153-161. 